\title{
Article \\ Evaluating the Effects Related to Restocking and Stock Replenishment of Penaeus penicillatus in the Xiamen Bay, China
}

\author{
Jia-Qiao Wang ${ }^{1,2}$, Yi-Jia Shih ${ }^{1,2}$, Liang-Ming Huang ${ }^{1,2}$, Jun Li ${ }^{1,2}$, Wei-Wen Li ${ }^{3}$, Chun-Han Shih 4 \\ and Ta-Jen Chu 1,2,*(D) \\ 1 Fisheries College, Jimei University, No. 185 Yinjiang Rd., Jimei District, Xiamen 361021, China; \\ skyofstar1@163.com (J.-Q.W.); eja0313@163.com (Y.-J.S.); lmhuang@jmu.edu.cn (L.-M.H.); \\ lijun1982@jmu.edu.cn (J.L.) \\ 2 Fujian Provincial Key Laboratory of Marine Fishery Resources and Eco-Environment, Xiamen 361021, China \\ 3 Third Institute of Oceanography, Ministry of Natural Resources, Xiamen 361005, China; liweiwen@tio.org.cn \\ 4 Department of Leisure \& Tourism Management, Shu-Te University, Kaohsiung 824, Taiwan; \\ f92b45028@ntu.edu.tw \\ * Correspondence: chutajen@gmail.com
}

check for

updates

Citation: Wang, J.-Q.; Shih, Y.-J.; Huang, L.-M.; Li, J.; Li, W.-W.; Shih, C.-H.; Chu, T.-J. Evaluating the Effects Related to Restocking and Stock Replenishment of Penaeus penicillatus in the Xiamen Bay, China. J. Mar. Sci. Eng. 2021, 9, 1122. https://doi.org/10.3390/jmse9101122

Academic Editor: Gabriella Caruso

Received: 14 September 2021

Accepted: 9 October 2021

Published: 14 October 2021

Publisher's Note: MDPI stays neutral with regard to jurisdictional claims in published maps and institutional affiliations.

Copyright: (c) 2021 by the authors. Licensee MDPI, Basel, Switzerland. This article is an open access article distributed under the terms and conditions of the Creative Commons Attribution (CC BY) license (https:// creativecommons.org/licenses/by/ $4.0 /)$.

\begin{abstract}
The quantitative evaluation of restocking and stock replenishment is essential for providing operational feedback and implementing adaptive management for future restoration projects. Since 2010, approximately 700 million juvenile shrimp (Penaeus penicillatus) have been released into Xiamen Bay, Fujian Province, China, each year, through stock replenishment programs. The recruited shrimp were sampled through three-year bottom trawl surveys from 2014 to 2017. The biological characteristics and catch equation were used to evaluate the effect of restocking and stock replenishment. The analysis uses the FAO-ICLARM Stock Assessment Tool (FISAT II) program. In general, there are two sources of recruitments-one from spawning brood stock and the other from released juvenile shrimp. We constructed an evaluation model for an effect evaluation based on Baranov's catch equation to separate the initial recruitment volume using survey data. The relationship between body weight and total length was $W=1.638 T L^{2.9307}$. There is no statistically significant difference between males and females. The von Bertalanffy growth parameters derived for prawns, using FiSAT II, were $L_{\infty}=209.6 \mathrm{~mm}$ and $K=0.51$ per year. In spring 2014, the initial resource amount was 49,200, while the ratio of effective recruitment and parent amount was 3.92. The survival rate of the released shrimp larvae, $1.88 \% 00$, seems to be very unsatisfactory. The resource amount in summer and autumn is higher than in winter and spring. Obviously, the restocking effect is lower and the programs need to be improved. To improve the restocking effect, the replenishment performance should be adjusted to reduce the mortality rate and increase its release effectiveness. Therefore, corresponding implementations are recommended, including standard extensive culture, reduction in stress during transportation, and temporary culture.
\end{abstract}

Keywords: Penaeus penicillatus; restocking; stock enhancement; fisheries enhancement; resource assessment model

\section{Introduction}

In many offshore and pelagic fisheries in the world, nearly $90 \%$ of marine fish resources have been fully exploited, overexploited, or depleted, and are affected by the degradation of aquatic habitats [1]. Global capture fisheries production has stagnated, while seafood demand has steadily increased [1,2]. However, for some coastal fisheries, restocking, stock replenishment, and sea ranching via the application of aquaculture technology are also expected to help to restore the lost production and possibly increase harvests beyond the original level [3]. The improvement of fisheries based on aquaculture is a set of management methods that involve the release of cultured organisms to enhance, protect, or restore the 
population. This definition covers a variety of improved fisheries systems, including 'sea ranching', 'restocking', and 'stock replenishment' [2,4,5]. Stock replenishment was defined as the release of cultured juveniles into wild populations to augment the natural supply of juveniles and optimize harvests by overcoming recruitment limitations [2-5]. Meanwhile, restocking was defined as the release of cultured juveniles into the water environment, including oceans, rivers, reservoirs, and lakes, for subsequent growth and harvesting, with the released aquatic organisms contributing to the biomass $[2,4,5]$. This form of enhancement of fisheries (stock replenishment and restocking) has played a vital role in recruiting populations, and has great potential to help to replenish depleted wild populations by releasing the offspring spawned from wild parents into the sea [2].

The evaluation of the effect of stock replenishment was an important link in the restoration of fisheries, and the procedures could provide an option for management for the utilization and resource conservation of sustainable fisheries [4]. In general, the population assessment was mainly carried out using mark and recapture technology, which includes in vitro listing marking [6], metal wire code marking [7], archival marking [8], and molecular marking [9]. Some studies include evaluating the reproduction and restocking effects of Japanese yellow croaker (Nibea japonica) and black sea bream (Sparus microcephalus) in Zhoushan waters [10], the effectiveness of Nibea albiflora stock replenishment in Xiangshan Bay [11], an overview of salmon stock replenishment in Southeast Alaska and its compatibility with the maintenance of hatchery and wild stocks [12], and evaluating the enhancement and restocking effect of Sepiella maindroni off the coast of Northern Zhejiang waters [13]. However, only a few studies have conducted relevant evaluations on shrimp.

Penaeus penicillatus Alcock, 1905 (Fenneropenaeus penicillatus), is called redtail prawn, as per the United Nations Agricultural Food Organization (FAO) [14]. In the 1980s, it was an important species, which was caught and cultured on the southeast coast in China, and the catch amount could reach 100 to 200 tons. In the early 1980s, the wild stock of $P$. penicillatus declined severely due to overfishing, environmental degradation, and engineering construction. Since 2005, it has been listed as an endangered species and entered the Red List of Species in China [15]. Ruan and Gong proposed implementing a fishing ban to protect the brood stock resources of Penaeus prawns in Xiamen waters [16].

Xiamen Bay is located on the southeast coast of Fujian Province and belongs to the subtropical ocean monsoon climate zone. The freshwater river flowing into the bay is mainly from Jiulong River, which is the second largest river in Fujian Province. Due to the unique geographical and landform characteristics, the fisheries resources are rich, and it is the spawning ground for many fish and shrimp [17]. Before the 1980s, P. penicillatus had abundant resources; however, with the overfishing of fisheries and the deterioration of the habitat, the numbers have dropped drastically and the fish have almost disappeared. Some studies include the biology, aquaculture ecology, seed breeding, diseases, genetics, and breeding technology [18-21], marked release in Dongwuyang, Fujian Province [22], restocking status, and protection strategy in Luoyuan Bay [17].

In China, since 1985, stock replenishment and restocking have played an important role in protecting shrimp stocks and maintaining the sustainable development of coastal fisheries, which cannot be overemphasized [23]. Since the 1990s, shrimp stock has been released in Luoyuan Bay, Pinghai Bay, Dongshan Bay, and Xinghua Bay for many consecutive years. Indeed, since 2003, a total of 4.6 billion shrimp stocks have been released into Xiamen Bay alone. In recent years, about 400 million P. penicillatus, Litopenaeus japonicus, and new prawns have been released each year. From 2003 to 2017, the total release of P. penicillatus in the waters of Xiamen Bay reached billions, but, so far, no research evaluating the effect of this has been conducted [24].

To manage shrimp fisheries resources and sustainability in Xiamen waters, biological information and population assessments are needed. This research aims to analyze the biological aspect of redtail prawn (P. penicillatus) in Xiamen waters, consisting of the sex ratio, length-weight analysis, growth parameter, level of exploitation (natural mortality rate, fishing mortality rate, and total mortality rate), and evaluation of stock replenishment 
and restocking. We have particularly constructed an assessment model to evaluate the effect based on Baranov's catch equation, which can separate the amount of initial recruitment using survey data from 2014 to 2017. The aim of this research, which analyzes the biological characteristics and restocking effects of P. penicillatus in Xiamen Bay, is to provide an idea regarding the effect of fisheries replenishment and restocking, provide suggestions on how to improve the effects, and serve as a reference for formulating redtail prawn management policies and the conservation of fisheries resources.

\section{Materials and Methods}

\subsection{Study Area}

The study area is in Xiamen Bay $\left(117^{\circ} 50^{\prime}-118^{\circ} 20^{\prime} \mathrm{E}\right.$ and $\left.24^{\circ} 14^{\prime}-24^{\circ} 42^{\prime} \mathrm{N}\right)$ and has a total marine area of $1281 \mathrm{~km}^{2}$ (Figure 1). It is a semi-enclosed bay, and the whole area includes the eastern areas (including Tong'an Bay, the Dadeng-Xiaodeng region, and Weitou Bay) with a sandy substrate and the western areas (including Western Harbor and Jiulong River Estuary), which are characterized by estuarine processes [25]. The water depth around the bay ranges from 6 to $25 \mathrm{~m}$, and the bay has a deep-water coastal area of $30 \mathrm{~km}$ [26]. The bay contains many habitat types (including mangrove wetlands and sandy beaches) and diverse biological groups [27]. Xiamen Bay is an important economic region for Xiamen as well as the whole of Fujian Province. There are numerous ports, transport infrastructure, shipbuilding, and petrochemical industries. Therefore, the area is also affected by intensive development activities, including shipping, aquaculture, reclamation, and tourism. These activities have led to several issues, including a decline in marine biodiversity, habitat loss, and water pollution [28].

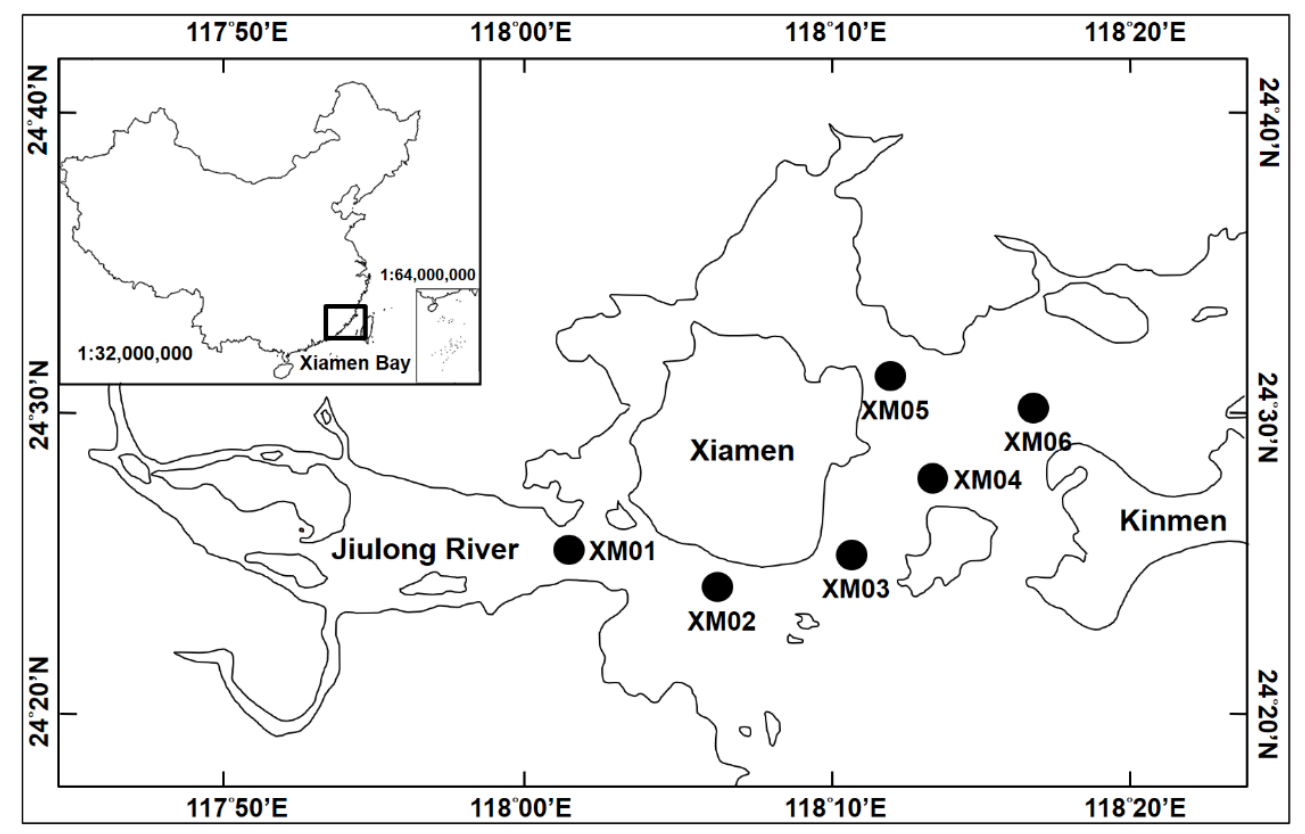

Figure 1. Map showing the location of the sample stations (XM01, XM02, XM03, XM04, XM05, and XM06) in Xiamen waters.

The biotic survey was conducted at six sample stations (Figure 1). These stations are briefly described as follows: XM01 includes the estuary of Jiulong River with larger freshwater exchange and mud sedimentation, where the seabed substrata are muddy because of the river's material deposition. XM02 and XM03 are located within the shallow waters, which face the open sea, with a substrate with mud-sand mixing and fluent water exchange. Compared to site XM02, site XM03 is better sheltered from monsoon wind waves. In addition, XM02 is at the front of the open zone with the greatest depth. Additionally, it stands where the wave current is the strongest, but also has the most drifted sand. Sites 
XM04, XM05, and XM06 are behind Kinmen Island and Xiaokinmen Island, especially site XM06, which is located at the mouth of Tongan Bay, a semi-enclosed water environment. A lot of sludge is deposited at Tongan Bay behind the bay mouth because of the sea water backflow.

\subsection{Biological Sampling}

From May 2014 to February 2017, field surveys were conducted to explore the effect of stock replenishment and restocking of the P. penicillatus population in Xiamen Bay, China. A total of 6 sites (Figure 1) were set up to conduct biological sampling. The "Minlongyu 62,678 Fishing Boat" in Longhai City was used, and twelve cruises were performed as a seasonal sampling in February, May, August, and November. The vessel was a single-boat truss bottom trawler with a main engine power of 330 kilowatts. The height of the bottom trawl net mouth was $2.5 \mathrm{~m}$, the length of the net was $24 \mathrm{~m}$, the mesh of the bag net was $20 \mathrm{~mm}$, the width of the truss was $27 \mathrm{~m}$, and the average towing speed was $2-3 \mathrm{n} \mathrm{mile} / \mathrm{h}$. Surveys were conducted in accordance with the "Regulations for the Survey of Marine Fishery Resources (SC/T 9403-2012)". Towing took place approximately parallel to the coastline at a speed of 2.5 knots for $1 \mathrm{~h}$.

After lifting the net, all the catch was poured onto the deck. All unwanted debris, plants, and garbage were first removed from catches; thereafter, the remainder was sorted into fish and shrimp categories. The shrimp and fish were put in marked plastic bags, and samples were frozen for species identification and further analysis in a laboratory. The crustacean samples were thawed in the laboratory, rinsed, and species identification, counting, weighing (g), and biological parameter determination at substations were performed; males and females were identified; the total length $(\mathrm{mm})$ and carapace length (mm) of all samples of P. penicillatus were measured. A total of 312 shrimps (172 females and 140 males) were collected for the present study.

\subsection{Biological Characteristics}

The length-weight relationships were determined according to the allometric equation given by Sparre and Venema [29], as follows:

$$
W=a L^{b}
$$

where $W=$ weight $(\mathrm{g}), L=$ total length $(\mathrm{mm}), a$ is the proportionality constant, and $b$ is the isometric exponent or slope indicating isometric growth, also known as the power exponent coefficients. The weight-length relationships were also determined for each sex. The $t$ test was used to analyze differences in total lengths and the weights of the sexes.

Growth in length and weight was analyzed separately for each sex using the von Bertalanffy growth function (VBGF). By means of the input data from the length frequencies and the FiSAT II program, the asymptotic length $\left(L_{\infty}\right)$ and the growth coefficient $(K)$ were estimated.

$$
\begin{aligned}
L_{t} & =L_{\infty}\left[1-e^{-K_{\left(t-t_{0}\right)}}\right] \\
W_{t} & =W_{\infty}\left[1-e^{-K_{\left(t-t_{0}\right)}}\right]^{b}
\end{aligned}
$$

Data analysis was conducted with the most recent version of FiSAT statistical software $[30,31]$. The instantaneous rate of natural mortality $(M)$ was obtained using Pauly's empirical formula [32]. The annual average surface water temperature $T$ was $21.6{ }^{\circ} \mathrm{C}$ in Xiamen Bay.

$$
\text { In } M=-0.0066-0.279 \times \operatorname{In} L_{\infty}+0.6543 \times \operatorname{In} K+0.463 \times \ln T
$$

The instantaneous rate of total mortality $(Z)$ was found from the estimate of the growth parameters $\left(K, L_{\infty}\right)$, using the length-converted catch curve method (FiSAT II software) [31]. 
The instantaneous rates of fishing mortality $(F)$ were calculated by the subtraction of the estimates of $M$ from $Z$, as follows:

$$
F=Z-M
$$

The exploitation rate was calculated as follows:

$$
E=F / Z
$$

Then, the total mortality $(A)$ was obtained using the follow equation:

$$
A=1-e^{-z} \text { or } A=1-S
$$

The derived estimates were then compared with other studies to allow further assessment.

\subsection{Biomass Estimation}

A method for assessment of stocking was developed and applied based on stock assessment theory and methods. Shrimp biomass was calculated using the swept area method [33]. The swept area $\left(a, \mathrm{~nm}^{2}\right)$ or 'effective path swept' for each tow was calculated as follows:

$$
a=v \times t \times B
$$

where $a$ is the sweeping area of each tow, $v$ is the towing speed, $t$ is the duration of the towing, and $B$ is the width of the path swept by the trawl (the width of the truss bar in this study is $27 \mathrm{~m}$ ).

Catch rates were calculated as catch $(C, \mathrm{~kg})$ divided by the time spent trawling $(t, h)$ and converted to catch per unit area (CPUA, $\mathrm{kg} / \mathrm{nm}^{2}=$ biomass $\mathrm{b}$ per unit area) by dividing by the swept area $((C / t) /(a / t)=C / a)$.

The formula of the average abundance $(\bar{N}, \mathrm{~kg})$, total biomass, was calculated from the following:

$$
\bar{N}=\frac{A r \times\left(\sum_{i=1}^{i=n} \frac{c_{i}}{a_{i}}\right)}{q \times n}
$$

where $C / a$ is the CPUA of all tows ( $\mathrm{kg}$ /square kilometers), ai is the sweeping area of the $i$-th station, $c i$ is the number of catches at the $i$-th station, $q$ is the proportion of catches $(0.5$ in this study; we assumed that all shrimps in the path of the tow would be captured), $A r$ is the overall area (154.18 square kilometers in this study), and $n$ is the total number of tows, which is derived from the number of survey stations in all seasons. The survey frequency is quarterly in this study. Therefore, the average abundance in that year is the average value from the four quarters.

\subsection{Model Building and Biomass Assessment}

Generally, the spawning season of P. penicillatus is between April and May in Xiamen Bay. To facilitate calculation and setting conditions, we assume that all spawning will be completed on 1 May (ts: time of spawning). The release time is generally 15 June. This time is usually around the international ocean week (8 June). Therefore, we assume that $\mathrm{P}$ is the number of spawning shrimps in the natural sea area, te is the annual release time of juvenile shrimp (te: release time of stock replenishment), $\operatorname{tr}$ and $N R$ are the recruitment time and the number of recruitments for juvenile shrimp to enter the fisheries, respectively. At this time, there are two sources of recruitments $N R$; one is from spawning brood stock NRP and the other is from released juvenile shrimp $N R r$. The schematic diagram of assessment model is shown in Figure 2.

$$
N R=N R P+N R r
$$




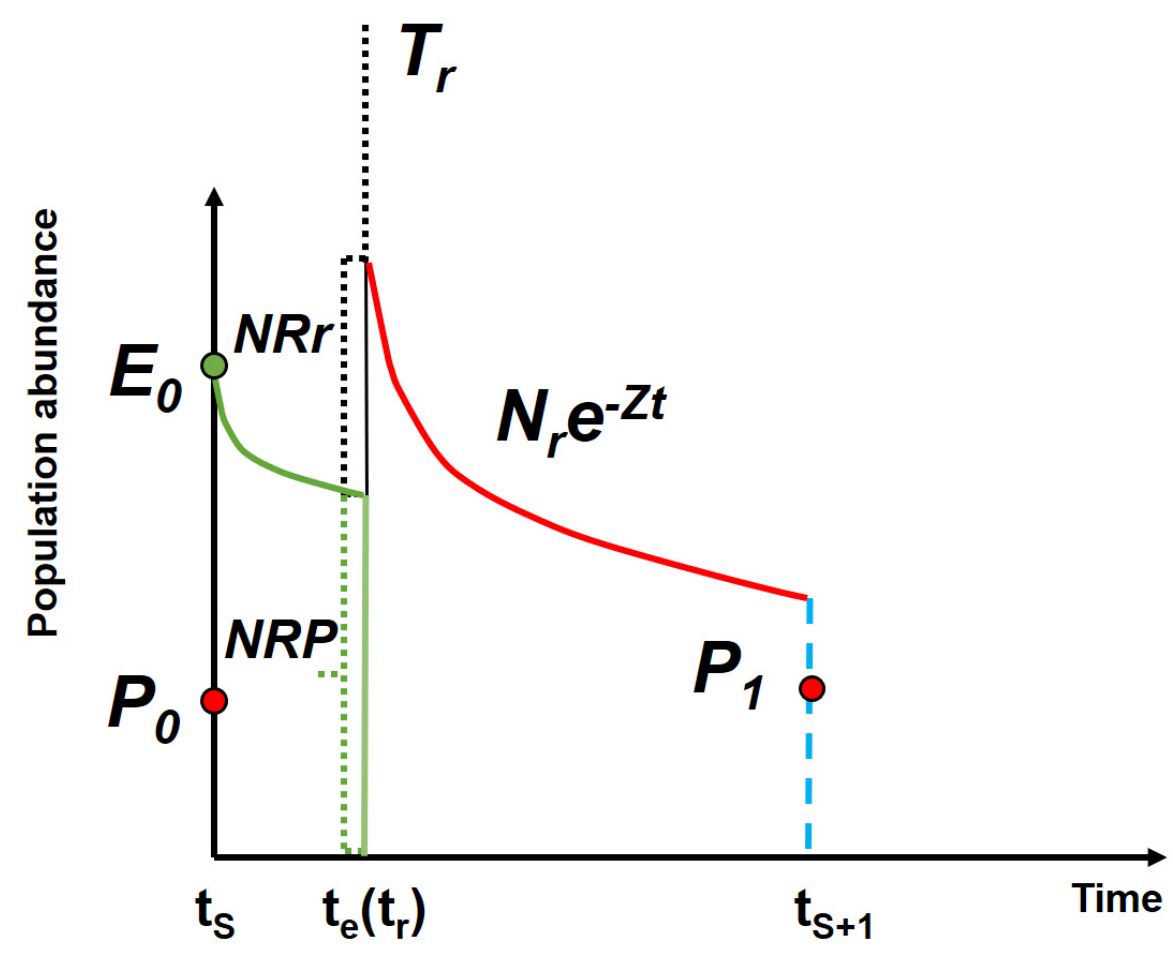

Figure 2. Map showing the schematic diagram of the assessment model.

According to Baranov's catch equation, the average abundance during the interval is as follows:

$$
\bar{N}=N \times A / Z
$$

where $\bar{N}$ is average abundance and $N \times A=$ total deaths.

Then, a simplified algorithm can be conducted for three years, which can estimate the number of initial recruitments.

The average abundance for the first year can be constructed in the form of the following equations:

$$
\begin{gathered}
\frac{\left(P C_{r}+R_{t} S\right) \times A_{t}}{Z_{t}}=\overline{N_{t}} \\
N R P=P \times C r \\
N R r=R t \times S
\end{gathered}
$$

The average abundance for the second and the third year can be constructed in the form of the following equations:

$$
\frac{\left(P C_{r}+R_{t} S\right) \times e^{-z_{t}} \times \alpha_{t} \times C_{r}+R_{t+1} S}{Z_{t+1}} \times A_{t+1}=\overline{N_{t+1}}
$$

$$
\frac{\left(P C_{r}+R_{t} S\right) \times e^{-z_{t}} \times e^{-z_{t+1}} \times \alpha_{t} \times \alpha_{t+1} \times C_{r}^{2}+R_{t+1} S \times e^{-z_{t+1}} \times \alpha_{t+1} \times C_{r}+R_{t+2} \times S}{Z_{t+2}} \times A_{t+2}=\overline{N_{t+2}}
$$

where, the following apply:

$P$ is the amount of female brood stock in natural seas. This value represents the amount of brood stock in the previous period, which will determine the number of next-generation juvenile shrimp.

$C_{r}$ is the conversion ratio, which represents the ratio between the recruitment amount entering the fishing area in natural seas and the amount of brood stock $P$.

$t$ is the period of released shrimps within the year.

$R_{t}$ is the number of shrimps released from artificial farming each year. 
$\alpha_{t}$ is the ratio of the number of females to the total resources at time $t$.

$S$ is the survival rate of released shrimps entering the fishing area.

$A_{t}$ is the total mortality of shrimp in a natural sea area at time $t$.

$Z_{t}$ is the total mortality coefficient of shrimp in a natural sea area at time $t$.

$\bar{N}$ is the average abundance of shrimp in a natural sea area at time $t$.

The above continuous Equation (4) includes a total of eight parameters, where $R_{t}$ can be obtained from the website of Xiamen Municipal Bureau of Marine Fisheries, $A_{t}$ and $Z_{t}$ can be obtained by the body length transformation catch curve method in the FiSAT II software, and $t$ can be calculated by the sea sweeping area method and substituted into Equation (12). Finally, we can calculate the value of $N_{0}, C_{r}$, and $S$ by solving the continuous equations.

We assumed that (1) the population is a one-year-old species, that is, one year of sexual maturity, and the parent dies after laying eggs; (2) there is no difference between the released population and the natural one in the sea area, and they are fully mixed; (3) after the release activity, the fishing and natural mortality coefficients of this population generation are constant; (4) the reproduction rate is consistent every year; (5) there is poor mobility of species, and it is assumed that there is no population moving in and moving out in the sea area.

\section{Results and Discussion}

\subsection{Biological Information and Growth Estimation}

During the period from 2014 to 2017 , a total of 312 shrimps (172 females and 140 males), with a total of $7573.18 \mathrm{gm}$, were collected from 12 cruises. Among different stations, the largest number was a total of 77 prawns, $1423.51 \mathrm{gm}$, accounting for $24.68 \%$ of the total catch number and $18.80 \%$ of the total catch weight, obtained at station XM05. In contrast, the smallest number was 20 tails, $436.6 \mathrm{gm}$, accounting for $6.41 \%$ of the total catch number and $5.77 \%$ of the total catch weight, obtained at station XM02.

The number of shrimps caught in summer and autumn is higher than that in winter and spring. Among them, 107 shrimps were caught in summer and autumn, accounting for $34.29 \%$ of the total catch, while 21 shrimps were caught in winter and 77 in spring, which accounted for $6.73 \%$ and $24.68 \%$ of the total catch, respectively. The highest catch weight in autumn and the lowest in spring, which are $3623.30 \mathrm{~g}$ and $754.13 \mathrm{~g}$, accounted for $47.84 \%$ and $9.96 \%$ of the total catch weight, respectively.

The size frequency data are plotted in Figure 3. The total length of the shrimps was 62 to $191 \mathrm{~mm}$, the main range was 100 to $150 \mathrm{~mm}(63.14 \%)$, the weight range was 2.8 to $79.6 \mathrm{gm}$, and the main range was 10.0 to $20.0 \mathrm{gm}(31.41 \%)$. There are obvious seasonal changes here. The figure also shows the season when the recruitment group enters the sea and the state of seasonal growth.

For females, the smallest individuals $(75 \mathrm{~mm} \mathrm{TL})$ were observed in the months of May, June, August, and September, while the largest sizes $(>215 \mathrm{~mm}$ ) were found in all the months (Figure 2). Most individuals, however, fell within the range of 145 to $195 \mathrm{~mm}$ $T L$. The smallest male individual $(65 \mathrm{~mm} T L)$ was found in the month of June, while large sizes (>215 mm) were found in the month of May (Figure 3). Most female shrimps fell within the range of 115 to $155 \mathrm{~mm}$ TL. These results reveal that males are generally larger than females.

The weight-length equations obtained were as follows (Figure 4):

$$
W=1.638 T L^{2.9307}\left(\mathrm{R}^{2}=0.9800, \mathrm{n}=312\right)
$$




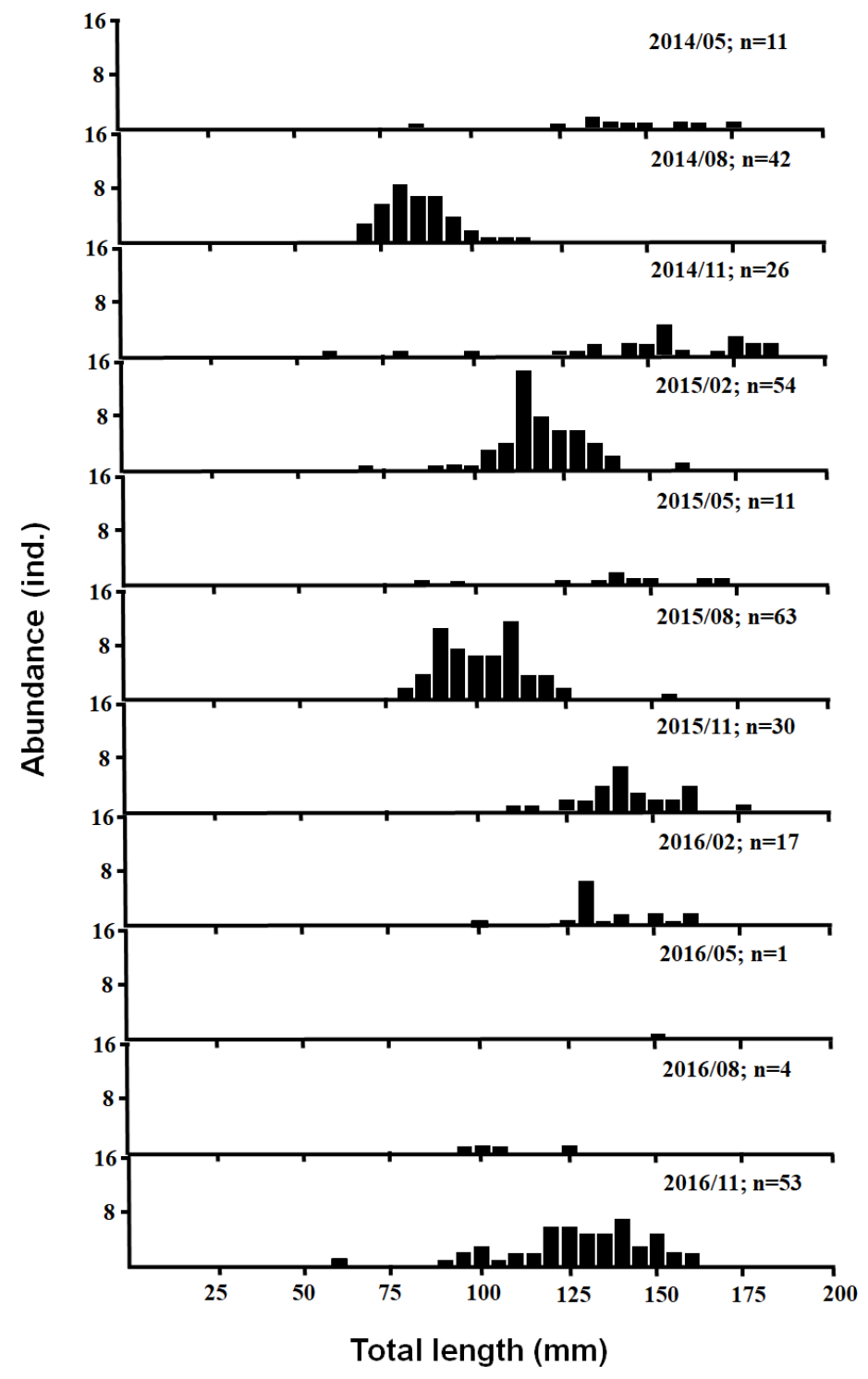

Figure 3. Size frequency data compiled from different seasons.

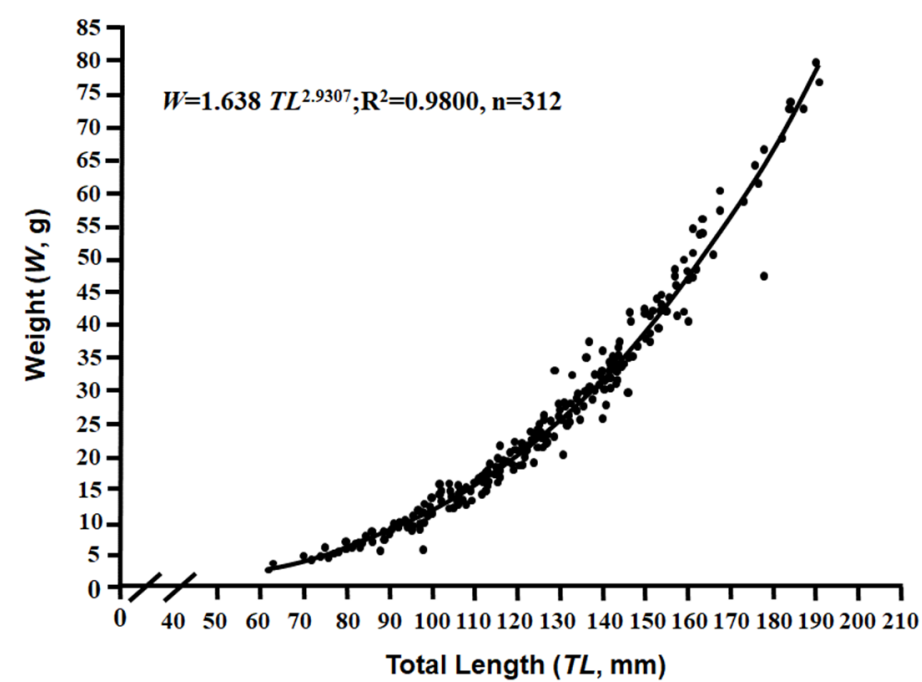

Figure 4. The relationship between body length and body weight of P. penicillatus in Xiamen Bay from 2014 to 2017. 
In general, there are two kinds of allometric growth patterns, positive allometric $(b>3)$ and negative allometric $(b<3)$. Positive allometric indicates that the growth in weight is dominant compared to length, while negative allometric indicates that the growth in length is more dominant than the growth in weight. This seems to imply that growth in length is more dominant than growth in weight.

The estimation of the growth parameters of P. penicillatus uses the von Bertalanffy equation, with length-frequency data as the input data in the FISAT II program (Figure 5). The growth coefficient $(K)$ value is 0.51 year $^{-1}$, and the asymptotic total length $\left(L_{\infty}\right)$ can reach $209 \mathrm{~mm}$.

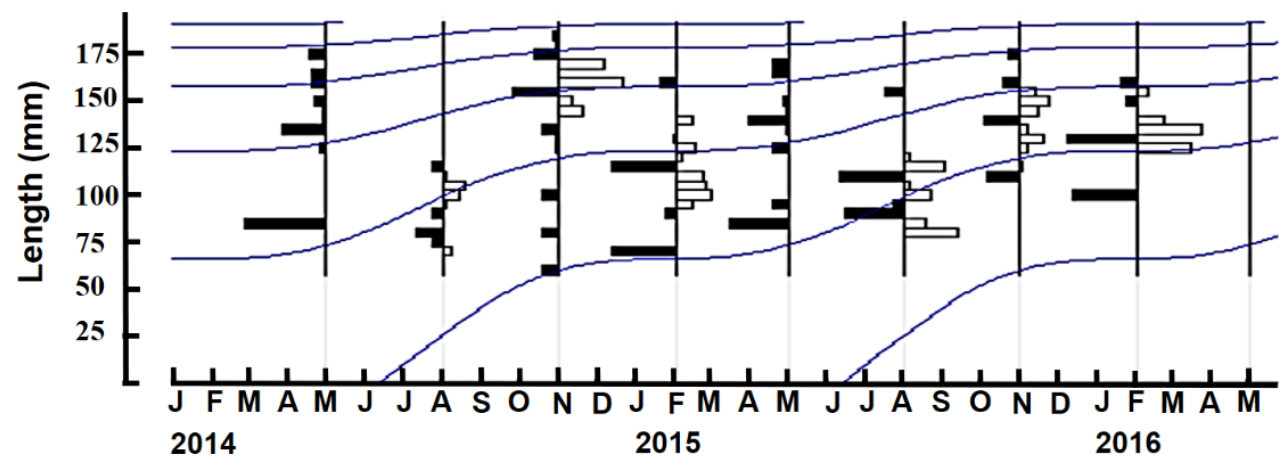

Figure 5. Size frequency data and the procedure using FiSAT II.

Regarding the weight-length equations obtained in this paper, $W=1.638 T L^{2.9307}$. Compared with the parameter of weight-length from the study of Chen and Hong [34], the coefficients of $a$ and $b$ are very close (Table 1 ). The results of the statistical $\mathrm{F}$ test show that there is no difference between males and females. However, Liu and Zhong [35] showed, in 1986, that males are heavier than females with the same body length. In contrast, the results of Wang et al. showed no difference between males and females [36].

Table 1. Comparison of the relationship between body length and weight of P. penicillatus.

\begin{tabular}{|c|c|c|c|c|c|c|c|}
\hline Period & Location & Source & Sex & Unit & $a$ & $b$ & Authors \\
\hline \multirow{2}{*}{1986} & \multirow{2}{*}{ South China Sea } & \multirow{2}{*}{ capture } & female & $\mathrm{mm}$ & $2.160 \times 10^{-5}$ & 2.8810 & \multirow[t]{2}{*}{ Liu and Zhong (1986) [35] } \\
\hline & & & male & $\mathrm{mm}$ & $5.464 \times 10^{-5}$ & 2.6420 & \\
\hline \multirow{2}{*}{1996} & \multirow{2}{*}{ Xiamen } & \multirow{2}{*}{ farming } & female & $\mathrm{mm}$ & $6.642 \times 10^{-6}$ & 3.1448 & \multirow[t]{2}{*}{ Wang et al. (1996) [36] } \\
\hline & & & male & $\mathrm{mm}$ & $6.316 \times 10^{-6}$ & 3.1543 & \\
\hline 1996 & Xiamen & farming & female & $\mathrm{cm}$ & $1.280 \times 10^{-2}$ & 2.9673 & Chen and Hong (1996) [34] \\
\hline \multirow{2}{*}{ 2014-2016 } & \multirow{2}{*}{ Xiamen } & \multirow{2}{*}{ capture } & male & $\mathrm{cm}$ & $1.320 \times 10^{-2}$ & 2.9503 & \multirow{2}{*}{ This study } \\
\hline & & & sex mix & $\mathrm{mm}$ & $1.638 \times 10^{-5}$ & 2.9307 & \\
\hline
\end{tabular}

Comparing the results of Liu and Zhong in 1986 with this 2014-2017 study, it is shown that both males and females are heavier in the 1986 study than they are in the results of this study [35]. This seems to imply that the weight of P. penicillatus is lighter in this study. The reason for the difference may come from different sea areas; Liu and Zhong conducted their study in the South China Sea [35], and this study (2021) was conducted in the waters of Xiamen, using the same ocean fishing method. However, comparing the different environment, aquaculture, and natural sea, the body size of the aquaculture [36] is smaller than the natural sea [35] and this study. Regarding the difference in growth between the marine environment and aquaculture environment, the growth of shrimp may be caused by environmental differences.

\subsection{Estimation of Mortality}

The results of the analysis showed that the instantaneous rate of the natural mortality $(M)$ of $P$. penicillatus was 0.5919 year $^{-1}$. In this study, the temperature used was $21.6^{\circ} \mathrm{C}$, which was the average water temperature in the three years in Xiamen waters. Then, the 
instantaneous rate of total mortality $(Z)$ was obtained using the length-converted catch curve method in the FiSAT II software, $Z=1.15$ year $^{-1}$ (Figure 6). Hereafter, the total mortality $(A)$ was 0.683 , the instantaneous rates of fishing mortality $(F)=0.5581$ year $^{-1}$, and the exploitation rate $(E)=0.485$ year $^{-1}$, respectively. According to Sparre and Venema (1992), the optimum exploitation ratio Eopt is 0.5, implying that the stock of P. penicillatus in Xiamen waters is heavily exploited.

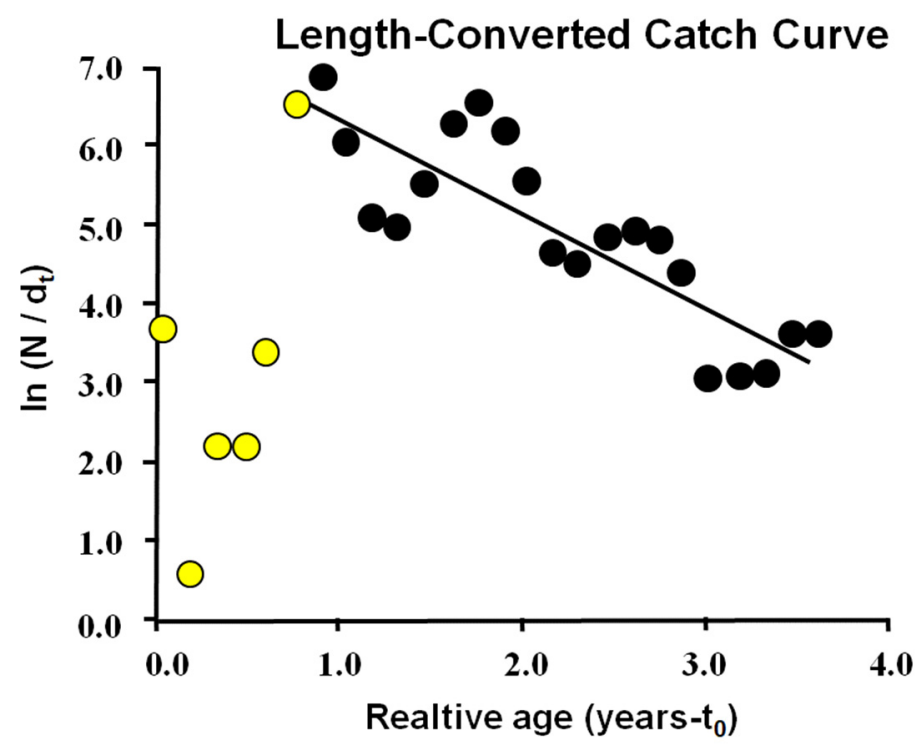

Figure 6. The length-converted catch curve as the determinant of mortality rate of P. penicillatus in Xiamen waters.

The optimum level of exploitation (Eopt) is 0.5 , beyond which the stock was said to be over-exploited [29]. This level implies that the stock of the P. penicillatus in Xiamen waters is exploited in a suitable state. Komi et al. reported a fishing mortality of $F=0.39$ year $^{-1}$, natural mortality of $M=1.640$ year $^{-1}$, total mortality of $Z=2.030$ year $^{-1}$, and exploitation rate of $E=0.1906$ of Metapenaeus elegans in the Andoni River, Nigeria, which indicated that the stock was under-exploited [37]. Another species of shrimp, Metapenaeus elegans of Segara Anakan Lagoon Cilacap, Central Java, showed overexploitation of this population, obtained from $F=6.760, M=1.430$, and $E=0.8830$ [38]. Nwosu also reported an overexploitation case of $P$. notialis, with $E=0.77$ in 2007 and $E=0.69$ in 2008 [39]. Most species of penaeid shrimps are over fished [40-42]. The exploitation rate could help understand the losses caused by fishing efforts and natural deaths, so that recommendations for management can be made. The catch deaths and natural deaths were almost equal, which also means that the biomass was not wasted in natural death. Therefore, the exploitation rate of $P$. penicillatus in Xiamen waters was conducive to management purposes. Such conditions could be harvested sustainably to maintain the socio-economic capacity and development of coastal communities.

\subsection{Estimation of Biomass and Replenishment Effect Assessment}

The regression equations were estimated based on the number of $P$. penicillatus in Xiamen bay from 2014 to 2017. They were $N t=404,630 \mathrm{e}^{-1.393 t}\left(\mathrm{R}^{2}=0.3737\right)$ in 2014 and $N t=1 \times 106 \mathrm{e}^{-1.393 \mathrm{t}}\left(\mathrm{R}^{2}=0.8568\right)$ in 2015. Meanwhile, the initial resources were estimated at 171 million in 2014 and 374.6 million in 2015. Moreover, the maximum survival rates were $2.37 \%$ o in 2014 and $2.67 \%$ o in 2015 .

Assuming that the instantaneous rates of total mortality $(Z)$ and total mortality $(A)$ in three years are the same, the data obtained above are substituted into 1.15 /year and 0.683 respectively. According to the survey data, the proportion of females in these three years are $0.5,0.6512$, and 0.5046 , respectively. At the same time, using the method of sweeping the sea area, it can be calculated that the average volume in the past three years is 76,000 , 
103,100, and 64,600. According to Equation (4), it can be calculated that for the initial female resource of P. penicillatus in the waters of Xiamen, the estimate was 49.2 thousand in the spring of 2014, while the ratio between the effective recruitment amount and the brood stock amount was 3.92, and the survival rate of released shrimp larvae was $1.88 \%$ oo.

Jiag et al. evaluated the recaptured yield and abundance of spawners originating from the hatchery-released juveniles of Nibea albiflora in Xiangshan Bay, with a mark-recapture experiment [11]. The natural and fishing mortalities of the hatchery-released individuals were $0.51 / a$ and $1.31 / a$, respectively. The effectiveness of $N$. albiflora stock replenishment is strongly dependent on the level of fishing effort, and an appropriate reduction in the fishing effort would benefit both the recapture yield and the abundance of spawners originating from hatchery-released juvenile N. albiflora. In this study, the survival rate of the larvae of P. penicillatus stock replenishment released in Xiamen Bay from 2014 to 2016 was 1.88\% The result showed that only a very small number of individuals could survive during the release process. This means that although billions of prawn larvae were released, the amount of resources in the sea was not well restored.

Wang used historical production to evaluate the release effect of $P$. penicillatus in Luoyuan Bay and believed that the recapture rate of release was between 5\% and 7\% [16]. An in vitro listing method evaluation of the reproduction and release effect of $P$. penicillatus in Sanduao waters was conducted [21], and the recapture rates of the two times release were $9.3 \%$ and $20.45 \%$, respectively. Lin et al. conducted multiple releases of prawns in Daya Bay waters. In vitro plastic labeling was carried out, and the results showed that the recovery rate of $P$. penicillatus was $5.0 \%$ [43]. The abovementioned studies seem to have very different results from the results of this article. We speculate that the main reason may be twofold, as follows: the size of the released juveniles is different, and the release process is different. We discussed the two release procedures and conditions of Guan et al. [21]. The average body lengths of the shrimp larvae were $7 \mathrm{~cm}$ and $10.72 \mathrm{~cm}$, respectively, and they were temporarily raised before release. Obviously, the use of larger juveniles and good temporary rearing is beneficial [21]. In contrast, regarding the release process and conditions of Lin et al., the body length of juvenile shrimp is between 1 and $5.7 \mathrm{~cm}$, which also seems to represent a small juvenile shrimp [36]. Compared with our conditions, the average body length of the shrimp released in Xiamen Bay, from 2014 to 2016, was $1 \mathrm{~cm}$. In short, the two conditions, including small individuals and no temporary rearing, may be the reason behind the higher mortality and lower fishing rate.

At that time, due to the small size of juvenile shrimp, it was not easy to use the method of marking in vitro, and the damage of the body surface was expected to cause many deaths, so this study did not use the method of marking and recapture evaluation. To overcome this problem, molecular labeling and isotope labeling seem to be more suitable methods for smaller release species. This is also an expected topic of ongoing research in the future. As we could not use the method of marking and recapture, we chose traditional fisheries resource evaluation. In this study, we used mathematical modeling to separate the two sources of recruitments. The highlight of this approach is that it confirms the effect of the release. Furthermore, the data used can basically be obtained through years of field surveys.

\subsection{Conservation Suggestions}

At this moment, the scientific basis for marine restocking, stock replenishment, and sea ranching continues to advance rapidly. The government assesses the possible contribution of these methods to fisheries management goals before designing enhancements and needs to be judged as having good potential, with the plan implemented effectively and responsibly [44]. It is widely recognized that there is a need to reduce fishing efforts and restore habitats to increase the resilience of capture fisheries [44]. However, the application of this technology still has a long way to go before an integrated management system that successfully solves all biological, ecological, social, cultural, and economic problems is in place [5]. The main challenges include determining when and where to use 
interventions to add value to management, integrating these initiatives with institutions and fisheries management regimes, monitoring the success of interventions, considering the cost effectiveness of culturing farmed juveniles, and releasing them into the wild, so that they survive in high proportions [5,44]. Marine ranching, which is considered a sustainable fisheries mode that has advantages for the ecosystem approach to fisheries [45], aquaculture, and capture-based aquaculture, is rapidly growing in China [45]. Habitat restoration and construction technology, stock replenishment, and the behavioral control of fisheries resources are some of the important methods of marine ranching [23,44-46].

Due to the small body length of the released juvenile P. penicillatus, their ability to resist impact is low. In addition, there are many predators in the environment. Ultimately, the number that can survive is limited. Therefore, in order to improve the survival rate of juvenile shrimps, corresponding implementations should be taken, including standard crude culture, reduction in stress during transportation, and temporary breeding. These implementations can improve the resources of $P$. penicillatus for the purpose of restoration in Xiamen Bay.

In addition, the factor of the habitat environment is also very important. This factor will have a great impact on the survival and growth of the prawn. With the development of the economy in Xiamen Bay, there are a lot of human-made disturbances, such as estuary pollution, marine garbage, seabed sand mining, and artificial land reclamation, etc. Reducing the damage to the habitat of the prawns requires the relevant departments to formulate corresponding implementations. For this, strengthening sewage treatment and monitoring, resolutely combating illegal sand mining, and salvaging seabed garbage are recommended, among others [46]. Improving the living environment and optimizing the habitat of $P$. penicillatus are meaningful implementations to increase the survival rate of the released prawns.

Illegal fishing is also one of the influencing factors [46]. Jiag et al. mentioned that the effectiveness of N. albiflora stock replenishment is strongly dependent on the level of fishing effort, and an appropriate reduction in the fishing effort would benefit both the recapture yield and the abundance of spawners originating from hatchery-released juvenile $N$. albiflora [11]. Thus, an appropriate reduction in the fishing effort is essential to improve its effectiveness. Therefore, we make the following recommendations:

1. Vigorously crack down on illegal fishing activities, including the confiscation and destruction of illegal fishing gear, and strengthen the punishment of offenders.

2. Conduct legal and ecological education to make relevant fishermen understand the importance of ecology, the environment, and resources.

3. Increase the number of patrols, regular patrols, and random inspections, so that illegal fishing personnel have nowhere to hide, and increase the cost of illegal fishing crimes.

4. Organize professionals from relevant scientific research institutions to regularly carry out publicity and education on marine biological resources and environmental protection, enter primary and secondary schools or communities, and improve the ecological awareness of ordinary people regarding protecting and caring for the ocean.

In the future, after the restoration of P. penicillatus in Xiamen Bay, the genetic diversity of the species must be ensured on a sustainable basis. In order to prevent all the released individuals from being close relatives, the gene integrity of Penaeus prawns in natural seas is destroyed. Therefore, in the process of releasing, it is necessary to collect and hatch eggs of different gene groups. Finally, enhancements enter into complex fisheries systems. It is crucial to consider the fisheries system, broad objectives for management, and the full range of management options when assessing the potential for developing and using enhancements [44,45].

\section{Conclusions}

Since 2010, approximately 700 million juvenile shrimp (P. penicillatus) have been released into Xiamen Bay, Fujian Province, China, each year, through stock replenishment programs. The biological aspect consists of length-weight analysis, growth parameters, 
level of exploitation (natural mortality rate, fishing mortality rate, and total mortality rate), and an evaluation of stock replenishment and restocking was conducted. An assessment model for effect evaluation, according to Baranov's catch equation, to separate the amount of initial recruitment, was constructed using survey data from 2014 to 2017. The survival rate of the released shrimp larvae, $1.88 \% 00$, seems to be very unsatisfactory. Obviously, the restocking effect is lower and the programs need to be improved. To improve the restocking effect, the replenishment performance should be adjusted to reduce the mortality rate and increase its release effectiveness. Therefore, corresponding implementations are recommended, including standard extensive culture, reduction in stress during transportation, and temporary culture. Of course, the results of this evaluation are unsatisfactory. We believe that the main limitations of the created evaluation model are the consequence of certain assumptions that were made. Therefore, identifying how to improve our ability to carry out successful evaluations is expected to be the focus of efforts in the future.

Author Contributions: Conceptualization, J.-Q.W. and T.-J.C.; methodology, J.-Q.W., T.-J.C. and Y.-J.S.; software, J.-Q.W., Y.-J.S. and T.-J.C.; validation, J.-Q.W., T.-J.C., Y.-J.S., C.-H.S. and L.-M.H.; formal analysis, J.-Q.W., T.-J.C., Y.-J.S. and C.-H.S.; investigation, J.-Q.W., Y.-J.S., T.-J.C., L.-M.H., J.L., W.-W.L. and C.-H.S.; resources, J.-Q.W., L.-M.H., J.L., W.-W.L. and Y.-J.S.; data curation, T.-J.C. and C.-H.S.; writing-original draft preparation, T.-J.C. and C.-H.S.; writing-review and editing, T.-J.C., C.-H.S. and Y.-J.S.; visualization, J.-Q.W., T.-J.C., Y.-J.S. and L.-M.H.; supervision, J.-Q.W. and T.-J.C.; project administration, J.-Q.W.; funding acquisition, J.-Q.W., T.-J.C. and Y.-J.S. All authors have read and agreed to the published version of the manuscript.

Funding: This work was supported by the Xiamen Civil Oceanic and Fishery Research Institute grant number HL20163 and Jimei University grant number C619061. The funders had no role in study design, data collection and analysis, decision to publish, or preparation of the manuscript.

Institutional Review Board Statement: Not applicable.

Informed Consent Statement: Not applicable.

Data Availability Statement: Not applicable.

Acknowledgments: This project was supported by the Fujian Provincial Department of Education (JAT190347), and the Cultivation program of National Natural Science Foundation of Jimei University (ZP2020023). We would like to thank the Xiamen Southern Ocean Research Center for supporting the cruises of biological surveys, and M.A. Li for his contributions to the revision comments on the manuscript. We would also like to thank the anonymous reviewers, whose useful suggestions were incorporated into the manuscript.

Conflicts of Interest: The authors declare no conflict of interest.

\section{References}

1. FAO. The State of World Fisheries and Aquaculture 2020. Sustainability in Action; FAO: Rome, Italy, 2020.

2. Lorenzen, K.; Leber, K.M.; Blankenship, H.L. Responsible approach to marine stock replenishment: An update. Rev. Fish. Sci. 2010, 18, 189-210. [CrossRef]

3. Bell, J.D.; Leber, K.M.; Blankenship, H.L.; Loneragan, N.R.; Masuda, R. A new era for restocking, stock replenishment and sea ranching of coastal fisheries resources. Rev. Fish. Sci. 2008, 16, 1-9. [CrossRef]

4. Bell, J.D.; Bartley, D.M.; Lorenzen, K.; Loneragan, N.R. Restocking and stock replenishment of coastal fisheries: Potential, problems and progress. Fish. Res. 2006, 80,1-8. [CrossRef]

5. Bartley, D.M.; Bell, J.D. Restocking, stock replenishment, and sea ranching: Arenas of progress. Rev. Fish. Sci. 2008, 16, 1-3. [CrossRef]

6. Liu, Y.; Yang, C.P.; Shan, B.B. Investigation of a mark-recapture method of black porgy, Acanthopagrus schlegelii, in Daya Bay using plastic oval tags. J. Fish. Sci. China 2019, 26, 63-70. (In Chinese) [CrossRef]

7. Xu, K.D.; Xu, H.X.; Wang, Y. The technology of coded wire tag and its application in fishery stock replenishment. Fish. Modernization 2018, 45, 75-80. (In Chinese)

8. Zhang, T.F.; Fan, W.; Dai, Y. Archival tags and geolocation methods for marine animals: A review. J. Appl. Ecol. 2015, 26, 3561-3566. (In Chinese)

9. Wang, W.J.; Zhang, K.; Luo, K. Assessment of recapture rates after hatchery release of Chinese shrimp Penaeus chinensis in Jiaozhou Bay and Bohai Bay in 2012 using pedigree tracing based on SSR markers. Fish. Sci. 2014, 80, 749-755. [CrossRef] 
10. Liang, J.; Wang, W.D.; Lin, G.Z. Effect and assessment of enhancement release of Nibea japonica and Sparus macrocephalus in artificial reef habitat waters of Zhoushan Zhejiang. J. Fish. Sci. China 2010, 17, 1075-1084. (In Chinese)

11. Jiag, Y.Z.; Lin, N.; Liu, Z.L.; Yuan, X.W.; Li, S.F.; Cheng, J.H. Effectiveness of Nibea albiflora stock replenishment in Xiangshan Bay and prioritization of fishing strategy for the released stock. J. Fish. Sci. China 2016, 5, 641-647. (In Chinese)

12. William, R.H. Overview of salmon stock replenishment in Southeast Alaska and compatibility with maintenance of hatchery and wild stocks. Environ. Biol. Fish. 2012, 94, 273-283.

13. Xu, K.D.; Xu, H.X.; Wang, Y. Effect and assessment of enhancement release of Sepiella maindroni in the northern coastal water of Zhejiang. J. Fish. Sci. China 2018, 25, 654-662. (In Chinese) [CrossRef]

14. Liang, H.F. Shrimp and Crab Biology; China Agriculture Press: Beijing, China, 2013. (In Chinese)

15. Tzeng, Y.Y. The Analysis of the Genetic Structure of Penaeus Penicillatus Alcock along the Southeast Coast of China; Xiamen Jimei University: Xiamen, China, 2013. (In Chinese)

16. Ruan, C.Y.; Gong, Z.C. The fishing ban should be implemented to protect the parent shrimp resources of Penaeus penicillatus in Xiamen inland sea. J. Fuj. Fish. 1984, 4, 101. (In Chinese)

17. Wang, Z.W. Discussion on the current situation of releasing and multiplication of Penaeus penicillatus in Luoyuan Bay and Its Protection Countermeasures. J. Fuj. Fish. 2006, 192, 95-97. (In Chinese)

18. Du, Q.; Wu, L.F. Optimum ratio of soya-lecithin in artificial feed for Penaeus penicillatus. J. Ocean. 1996, 15, 62-66. (In Chinese)

19. Zhang, G.L.; Li, Z.B.; Wang, Z.L. Study status and perspective of Penaeus penicillatus. Modern Fish. Info. 2010, 25, 7-10. (In Chinese)

20. Wang, C.Z.; Lin, G.R.; Yan, T. Microbial community in the shrimp (Penaeus penicillatus) intestine and its culture environment. J. Fish. Sci. China 2014, 38, 706-712. (In Chinese)

21. Chai, X.J. Discuss on feed a in Penaeus penicillatus Alock breeding. J. Zhejiang Ocean Univ. 2001, 20, 248-250. (In Chinese)

22. Guan, J.Z.; Zheng, X.L.; Ke, C.H. The tagging release of Penaeus orientalis and Penaeus penicillatus in Dongwu ocean, Fujian Province. Mar. Fish. 1984, 6, 243-248. (In Chinese)

23. Zhou, X.J.; Zhao, X.; Zhang, S.Y.; Lin, J. Marine ranching construction and management in East China Sea: Programs for sustainable fishery and aquaculture. Water 2019, 11, 1237. [CrossRef]

24. Fujian Provincial Department of Ocean and Fisheries. Obvious Ecological and Eco-Nomic Benefits Have Been Achieved by Fishery Enhancement and Release in Fujian Province. 2009. Available online: http://hyyyj.fj.gov.cn/ztzl/yyzybhsdxd/sdxd/ ssswzzfl/200904/t20090403_1861122.htm (accessed on 25 September 2021). (In Chinese)

25. Wang, X.; Wu, F.; Turvey, S.T.; Rosso, M.; Tao, C.; Ding, X.; Zhu, Q. Social organization and distribution patterns inform conservation management of a threatened Indo-Pacific humpback dolphin population. J. Mammal. 2015, 96, 964-971. [CrossRef]

26. Zhang, L.P.; Feng, H.; Li, X.X.; Ye, X.; Jing, Y.H.; Ouyang, T.; Yu, X.T.; Liang, R.Y.; Chen, W.Q. Heavy metal contaminant remediation study of western Xiamen Bay sediment, China: Laboratory bench scale testing results. J. Hazard. Mater. 2009, 172, 108-116. [CrossRef]

27. Hu, W.; Yu, W.; Ma, Z.; Ye, G.; Dang, E.; Huang, H.; Zhang, D.; Chen, B. Assessing the ecological sensitivity of coastal marine ecosystems: A case study in Xiamen Bay, China. Sustainability 2019, 11, 6372. [CrossRef]

28. Zhang, X.; Xue, X. Analysis of marine environmental problems in a rapidly urbanizing coastal area using the DPSIR framework: A case study in Xiamen, China. J. Environ. Plan. Manag. 2013, 56, 720-742. [CrossRef]

29. Sparre, P.; Venema, S.C. Introduction to Tropical Fish Stock Assessment. Part 1. Manual; FAO Fisheries Technical Paper, 306. No. 1, Rev. 1; FAO: Rome, Italy, 1992; 376p.

30. Gayanilo, F.C., Jr.; Sparre, P.; Pauly, D. The FAO-ICLARM Stock Assessment Tools (FISAT) User's Guide; FAO Computerized information series: Fisheries; FAO: Rome, Italy, 1994; 262p.

31. Gayanilo, F.C., Jr.; Sparre, P.; Pauly, D. FAO-ICLARM Fish Stock Assessment (FiSAT) Reference Manual; FAO Computerized information Series: Fisheries; FAO: Rome, Italy, 1997.

32. Pauly, D. On the interrelationships between natural mortality, growth parameters and mean environmental temperature in 175 fish stocks. J. Cons. Int. Explor. Mer. 1980, 39, 175-192. [CrossRef]

33. Sparre, P.; Venema, S.C. Introduction to Tropical Fish Stock Assessment. Part 2. Exercises; FAO Fisheries Technical Paper. 306. No. 2, Rev. 2; FAO: Rome, Italy, 1999; 94p.

34. Chen, Y.H.; Hong, X. Study on the relationship between body length and body weight of cultured Penaeus penicillatus. Fujian Fish. 1996, 4, 11-15. (In Chinese)

35. Liu, R.Y.; Zhong, Z.R. Shrimp Species in the South China Sea; Agriculture Press: Beijing, China, 1986; pp. 132-138. (In Chinese)

36. Wang, Y.Y.; Chen, S.X.; Fang, L.S. Relationship between body weight and length of pond-cultured Penaeus penicillatus. J. Ocean. 1996, 15, 25-31. (In Chinese)

37. Komi, G.W.; Francis, A.; Aleleye-Wokoma, I.P. Mortality and exploitation of Penaeus monodon in the Andoni River, Nigeria. J. Nat. Sci. Res. 2013, 3, 58-67.

38. Saputra, S.W. Stock analysis of Fine shrimp Metapenaeus elegans de Man (1907) using yield per recruit relative model (Y/R) at Segara Anakan Lagoon Cilacap Central Java. J. Coastal Dev. 2010, 14, 18-25.

39. Nwosu, F.M. Population dynamics of the exploited penaeid shrimp, Penaeus (Farfantepenacus notialis) in the Cross River Estuary, Nigeria. J. Fish. Int. 2009, 4, 62-67.

40. Lalitha, D.S. Growth and Population Dynamics of Three Penaeid Prawns in the Trawling Grounds of Kakinada; Kakinada Research Centre of CMFR Institute: Kakinada, India, 1987; 259p. 
41. Amin, S.M.N.; Arshad, A.; Siraj, S.S.; Sidik, B.J. Population structure, growth, mortality and yield per recruit of segestid shrimp, Acetes japonicus (Decapoda: Sergestidae) from the coastal waters of Malacca peninsular, Malaysia. Indian J. Mar. Sci. 2009, 38, 57-68.

42. Yassien, M.H. Biology and fishery of the Green Tiger prawn Penaeus semisulcatis de Haan (1850) in Bardawil Lagoon, Northern Sinai, Egypt. Egypt. J. Aqua. Res. 2004, 30, 271-280.

43. Lin, J.B.; Chen, T.; Chen, L. Studies on techniques and effects of prawn stock replenishment in Daya Bay. J. Fish. China 1997, S21, 24-30. (In Chinese)

44. Lorenzen, K.; Agnalt, A.L.; Blankenship, H.L.; Hines, A.H.; Leber, K.M.; Loneragan, N.R.; Taylor, M.D. Evolving context and maturing science: Aquaculture-based enhancement and restoration enter the marine fisheries management toolbox. Rev. Fish. Sci. 2013, 21, 213-221. [CrossRef]

45. Molony, B.W.; Lenanton, R.; Jackson, G.; Norriss, J. Stock replenishment as a fisheries management tool. Rev. Fish Biol. Fish. 2003, 13, 409-432. [CrossRef]

46. Cheng, J.H.; Jiang, Y.Z. Marine stock replenishment: Review and prospect. J. Fish. Sci. China 2010, 17, 610-617. (In Chinese) 